\title{
Gestational Exposure to Nonylphenol Causes Precocious Mammary Gland Development in Female Rat Offspring
}

\author{
Hyun Ju MOON ${ }^{1)}$, Soon Young HAN ${ }^{1}$, Jae-Ho SHIN ${ }^{1)}$, IL Hyun KANG ${ }^{1}$, \\ Tae Sung KIM ${ }^{1)}$, Jin Hwan HONG ${ }^{1)}$, Seung-Hee $\mathrm{KIM}^{1}{ }^{1}$ and Suzanne E. FENTON ${ }^{2)}$ \\ 1) Endocrine Toxicology Team, National Institute of Toxicological Research, Korea Food and \\ Drug Administration, Seoul 122-704, Korea and ${ }^{2}$ Reproductive Toxicology Division, National \\ Health and Environmental Effects Research Laboratory, U.S. Environmental Protection \\ Agency, North Carolina 27711, USA
}

\begin{abstract}
This study examined whether or not exposure to 4-nonylphenol (NP) during late gestation affects reproductive and mammary development in the offspring of female rats. Time pregnant Long Evans rats were gavaged with NP (10 or $100 \mathrm{mg} / \mathrm{kg}$ ), atrazine (ATR, $100 \mathrm{mg} / \mathrm{kg}$ ), or corn oil on gestation days 15-19. The uterus weights of the NP $(100 \mathrm{mg} / \mathrm{kg} / \mathrm{d})$-exposed pups were higher than those of the controls but the weights of the other organs were unchanged. Delayed mammary gland (MG) development was detected in the ATR pups on PND 4 and persisted through to PND 66. The high dose NP pups had advanced lobular development of their MG on PND 22, while the glands from the low dose NP pups were no different morphologically from the controls. Immunohistochemical comparisons of the mammary sections from PND 41 demonstrated low levels of estrogen receptor (ER) staining in the control gland stroma and epithelium but higher levels in the tissue of the pups exposed to NP and ATR. ATR also elevated ER in the stroma surrounding the epithelial layer of the terminal end buds. The level of progesterone receptor (PR) staining was markedly lower in the epithelium of the $100 \mathrm{mg} / \mathrm{kg}$ NP glands vs. the control glands. However, PR was present at high levels in the epithelium of the $10 \mathrm{mg} / \mathrm{kg}$ NP glands and was even more prominent in the ATRexposed ductal epithelium and fat cell nuclei. The level of prolactin staining was only elevated in glands containing lobule areas (NP-exposed) compared with the control levels. These results suggest that NP and ATR have opposite effects on the development of MG after gestational exposure. Exposure to them during the critical period of epithelial outgrowth altered the receptor levels of mammary progesterone and prolactin and might contribute to the differences in the mammary morphology at PND 41.
\end{abstract}

Key words: 4-Nonylphenol (NP), Atrazine, Endocrine disruptor, Hormone receptor, In utero exposure, Mammary gland, Rat

(J. Reprod. Dev. 53: 333-344, 2007)

$\mathbf{T}$ he branched-chain isomer 4-nonylphenol (NP) is metabolized microbiologically from nonionic surfactants, 4-nonylphenol ethoxylates [1, 2], and exhibits estrogenic effects by stimulating expression of the estrogen-responsive vitellogenin

Accepted for publication: November 13, 2006

Published online: December 27, 2006

Correspondence: H. J. Moon (e-mail: mhj1612@kfda.go.kr) gene in fish [3-5] and growth of human breast cancer MCF-7 cells [6]. NP also exerted uterotrophic activity in immature and mature ovariectomised female rats and induced early onset of vaginal opening in a 20-day pubertal assay [7-

\#This manuscript has been reviewed by the National Health and Environmental Effects Research Laboratory (NHEERL) of the U.S. EPA and approved for publication. Approval does not signify that the contents reflect the views of the Agency, nor does mention of trade names or commercial products constitute endorsement or recommendation for use. 
12]. NP functions as an activator and cell proliferator in the mammary gland (MG) through an estrogen receptor-mediated mechanism [13]. Colerangle and Roy [13] reported that doses of 0.073 and $53.2 \mathrm{mg} / \mathrm{kg} /$ day NP for 11 days via scimplanted minipumps caused a marked increase in the proliferation of MG cells in young Noble rats. These results suggest an approximate 600 -fold higher sensitivity of MG compared with the uterus in rodents. However, these results were not reproduced in Odum's [14] study, which was carried out with the same protocol using the same concentration and strain and with an even a higher concentration and different strain. In addition, they also found that when NP $(100 \mathrm{mg} / \mathrm{kg})$ was administered orally to pubertal rats (4-5 weeks) for 11 days, there was a higher number of type I lobules (containing up to 11 alveolar buds) and a lower number of terminal end buds (TEBs) in the peripheral region. This suggests that a high dose NP $(100 \mathrm{mg} / \mathrm{kg})$ can alter normal mammary gland differentiation in pubertal rats.

Atrazine (2-chloro-4-ethylamino-6-isopropylamino-S-triazine; ATR) is a widely used herbicide applied to a variety of crops to control broadleaf and grassy weeds. Previous studies have shown that ATR has adverse effects on the reproductive system $[15,16]$ and endocrine-regulated endpoints in rats $[17,18]$. ATR resulted in a delayed MG development in female offspring rats exposed in utero $[19,20]$, an earlier onset of mammary tumors in Sprague-Dawley rats following long-term oral exposure [21,22]. Based on these results, this study used ATR as reference for comparing the development of MGs.

Generally, exposure to hormonally active toxicants during sexual differentiation can produce adverse effect in the reproductive organs of humans and wildlife. Several studies have demonstrated that in utero exposure to environmental estrogens might produce the greatest estrogenic effects in human and rodent males [23, 24]. Late pregnancy and puberty are critical periods of mammary development that can be altered by hormones, growth factors [25], and environmental agents [26]. There have been few studies of the effects of in utero NP exposure on MG development in rats. This study examined whether or not in utero NP exposure can induce changes in MG and reproductive development in female offspring. In addition, the relationships between mammary development and expression of hormone receptors, such as estrogen receptor (ER), progesterone receptor (PR), and prolactin receptor (PRLR), were investigated using immunohistochemical staining.

\section{Materials and Methods}

\section{Chemicals}

The chemicals used in this study were obtained from the following sources. NP (a mixture of branched side chains containing $85 \%$ p-isomer) was purchased from Fluka Chemical (Ronkonkoma, NY, USA) and ATR (97.1\% purity) was a gift from Norvatis Crop Protection (Seoul, Korea). The monoclonal antibodies for ER and PR were obtained from Immunotech (Seoul, Korea), and the monoclonal anti-PRLR was purchased from ABR Affinity BioReagents (Golden, Fort Collins, CO, USA). The normal horse and mouse sera were supplied by Jackson ImmunoResearch Laboratories (West Grove, PA, USA.)

\section{Animals and treatment}

Ten-day timed pregnant Long Evans rats were purchased from Charles Rivers Laboratories (Raleigh, NC, USA) and maintained under controlled temperature (20-24 C), humidity (40$50 \%$ ), and light (14 h light/10 h dark) conditions. The animals were housed one per cage and given food (Purina Rat Chow 5001) and water ad libitum. The dams were assigned to the treatment groups based on their body weights on gestation day (GD) 15 such that all treatments groups had similar body weights ( $n=7-8 /$ treatment group). The dosing solutions for NP were prepared in corn oil at concentrations of 2 and $20 \mathrm{mg} / \mathrm{ml}$ and were used at a dosing volume of $5 \mathrm{ml} / \mathrm{kg}$ body weight. ATR was prepared as a suspension in 1\% methylcellulose (MC) in distilled water. The pregnant dams were administered the vehicle (corn oil), NP (10 and 100 $\mathrm{mg} / \mathrm{kg} /$ day $)$, or ATR (100 mg/kg/day) by oral gavage from GD 15 to 19 . The NP and ATR doses were chosen due to the consistent reproductive endpoint effects reported by Laws et al. [11,17]. All the dams were observed at least once daily for mortality, morbidity, any signs of injury, their general appearance, and signs of toxicity. Individual body weights were measured daily during the administration period. Total weight 
gain during pregnancy was calculated by subtracting the body weight on GD 15 from that on GD 19. The dams were allowed to deliver their pups naturally on GD 21. On postnatal day (PND) 4 (day of birth counted as day 1), all litters were randomly culled to 10 pups, with at least 6 females per litter in order to enable similar nutritional exposure to the test material for all pups. On the day of weaning (PND 22), the female offspring were separated from the males and housed 3-4 per cage. The dams and male pups were sacrificed, and the pups were necropsied.

\section{Necropsy}

The reproductive organs (ovary, uterus, and vagina) and pituitary weights of the female offspring rats were measured on PND 41. All the rats were decapitated, and their blood was collected into EDTA-treated tubes. The blood was centrifuged at 3,000 rpm and $4 \mathrm{C}$ for $10 \mathrm{~min}$, and the supernatant was separated from the clot and stored at $-80 \mathrm{C}$ prior to use. The uterus and ovaries of each rat were dissected and trimmed free of any adhering fascia and fat without any loss of luminal contents. The vagina was removed from the uterus at the level of the uterine cervix and weighed. The left mammary pad containing the fourth and fifth gland was dissected and used for immunohistochemical staining. The right mammary was processed for whole mount analysis.

\section{Mammary whole mounts}

The mammary whole mounts were prepared from the fourth and fifth glands, as described previously [43], on PND 4, 22, 33, 41, and 66. The glands were dissected and spread on glass slides, fixed in Carnoy's solution (ethanol:chloroform: glacial acetic acid, 6:3:1, v/v) overnight (14-18 h), rehydrated in $70 \%$ ethanol ( $15 \mathrm{~min})$, rinsed in water (5 min), and stained in carmine alum $(0.2 \%$ carmine and $0.5 \%$ aluminum potassium sulfate) overnight (14-18 h) at room temperature. The stained glands were progressively dehydrated in ethanol (70$100 \%$ ) in 3 steps (15 min/step), cleared in xylene, and permanently mounted. The whole mounts were visualized/photographed by optical microscopy $(20 \times)$ linked to an image analysis system (Image ProPlus, Seoul, Korea) to observe the scale of the mammary tree, epithelial growth, number of TEBs, and density of the alveolar buds (ABs). Two people who were blinded to the identity of the treatment group evaluated all the whole mounts, and the average result was reported. The degree of MG development was evaluated using the following morphological criteria: 1 ) the number of the primary branches and the size of the ductal tree occupied the mammary fat pad on PND 4;2) the growth (migration to lymph node) extending from the nipple to the peripheral region on PND 22;3) the degree of TEB development on PND 33, which was measured as the shortest distance in millimeters between two glands $\left(4^{\text {th }}\right.$ and $\left.5^{\text {th }}\right)$; and 4 ) the ductal sidebranching and density of ABs on and after PND 41. A well-developed gland was defined as a structure with a large mammary tree, a few TEBs/terminal ducts (TD), generous side-branching, and a high density of ABs through out the gland. TEBs are composed of 3-6 layers of closely packed mammary epithelial cells and show a rounded appearance at the end of the duct. TDs have a smaller diameter and are surrounded by a layer only 1-2 cells thick. Lobules are a group of alveoli branched from the main duct. ABs generally consist of 3-5 blind ductules in a cluster $[27,28]$. In this study, no attempt was made to distinguish between ABs and lobules.

\section{Immunohistochemistry}

Unstained slides were deparaffinized in xylene for $3 \mathrm{~min}$ followed by rehydration in a graded series of alcohol (100 and $95 \%$ ) for $3 \mathrm{~min}$ to automation buffer ( $\mathrm{pH}$ 7.5) (Biomeda, Temecula, CA, USA) containing $50 \mathrm{mM}$ Tris, $150 \mathrm{mM} \mathrm{NaCl}$, $0.02 \%$ nonionic detergent (Triton-X 100, NP-40, Tween-20 or BRIG 35) for $5 \mathrm{~min}$. The endogenous peroxidase activity was blocked with $3 \%$ hydrogen peroxide followed by washing in automation buffer for $5 \mathrm{~min}$. The slides were then placed in $0.01 \mathrm{M}$ citrate buffer and heated in a decloaking chamber for $5 \mathrm{~min}$. After cooling, the slides were washed with automation buffer and incubated with $0.1 \mathrm{ml}$ of normal horse serum (diluted 50x) for $20 \mathrm{~min}$ in order to block the nonspecific binding. The primary monoclonal mouse-antibodies for ER, PR, and PRLR were diluted 1:50 in buffer, and $0.1 \mathrm{ml}$ was applied to the slides, which were then incubated at room temperature for $1 \mathrm{~h}$. The sections were washed with automation buffer for 5 min and then incubated with $0.1 \mathrm{ml}$ of biotinylated goat anti-mouse secondary antibody (Dako, Glostrup, Denmark) (diluted 500×) for $30 \mathrm{~min}$. 
After washing with automation buffer for $5 \mathrm{~min}, 0.1$ $\mathrm{ml}$ of ABC Elite complex [diluted $200 \times$ in $1 \times \mathrm{PBS}$ containing $0.01 \%$ Tween 20 (pH 7.4); Deko] was applied to each section in the dark for $20 \mathrm{~min}$. The slides were washed with automation buffer for 5 min and visualized using 3,3-diaminobenzidine tetrahydrochloride (DAB).

\section{Radioimmunoassay}

Blood was collected from all animals at sacrifice. Serum was prepared and kept frozen at $-75 \mathrm{C}$ until needed to determine the serum hormone concentrations. The serum hormone (LH, FSH, TSH and prolactin) concentrations were measured as described previously [29].

\section{Statistics}

For statistical analysis, the data was grouped by experiment, as indicated in the tables and figures. The body weights, organ weights, and hormone concentrations were evaluated by one-way analysis of variance (ANOVA). Significance was indicated by $\mathrm{P}<0.05$.

\section{Results}

Body and reproductive tissue weights

A slight decrease in body weight was observed in the ATR dams when NP (10 and $100 \mathrm{mg} / \mathrm{kg}$ ) and
ATR (100 mg/kg) were administered to them by oral gavage during GD 15-19 (Fig. 1). Although not statistically significant, the ATR-exposed dams weighed less than the controls. The weights of the NP-exposed dams were similar to those of the controls. The offspring of dams treated with NP and ATR during lactation were similar to those of the controls at PND 4. Furthermore, there was no difference in body weight among the groups at PND 22, 33, 41 (Table 1), and 66 (not shown).

At the necropsy on PND 41, the female offspring exposed to $100 \mathrm{mg} / \mathrm{kg}$ NP showed significantly increased uterine weights. However, ATR

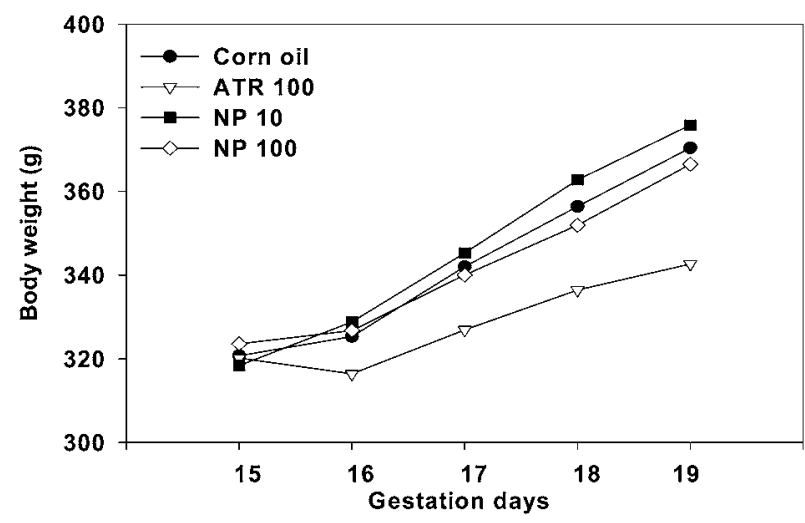

Fig. 1. Body weight changes in Long Evans time pregnant dams treated with nonylphenol (NP) and atrazine (ATR) during the 5-day exposure period.

Table 1. Body weights of rat pups exposed to nonylphenol (NP), atrazine (ATR), or corn oil in late pregnancy on postnatal days (PND) 4, 22, 33 and 41

\begin{tabular}{|c|c|c|c|c|}
\hline \multirow{2}{*}{$\begin{array}{l}\text { Mean pup } \\
\text { weight (g)/litter }\end{array}$} & \multirow[t]{2}{*}{ Vehicle } & \multicolumn{2}{|c|}{ Nonylphenol (mg/kg/d) } & \multirow{2}{*}{$\frac{\text { Atrazine }(\mathrm{mg} / \mathrm{kg} / \mathrm{d})}{100}$} \\
\hline & & 10 & 100 & \\
\hline PND 4 & $9.1 \pm 1.3$ & $9.0 \pm 1.5$ & $9.0 \pm 1.2$ & $8.7 \pm 1.1$ \\
\hline PND 22 & $54.0 \pm 4.5$ & $54.9 \pm 5.4$ & $52.3 \pm 5.3$ & $53.6 \pm 10.4$ \\
\hline PND 33 & $124.1 \pm 8.8$ & $124.0 \pm 14.6$ & $123.2 \pm 8.3$ & $127.2 \pm 9.5$ \\
\hline PND 41 & $181.1 \pm 7.1$ & $190.6 \pm 9.5$ & $184.6 \pm 10.5$ & $190.6 \pm 10.9$ \\
\hline
\end{tabular}

The weights of the control and NP- and ATR-exposed pups were similar throughout growth. The data is presented as means \pm SD.

Table 2. Relative organ weights of female offspring rats (PND 41) exposed in utero to nonylphenol (NP) or atrazine (ATR)

\begin{tabular}{|c|c|c|c|c|c|c|}
\hline \multirow{2}{*}{$\begin{array}{l}\text { Treatment } \\
(\mathrm{mg} / \mathrm{kg} / \text { day })\end{array}$} & \multirow{2}{*}{$\begin{array}{l}\text { Final B.W. } \\
\qquad(\mathrm{g})\end{array}$} & \multirow{2}{*}{$\begin{array}{c}\text { Pituitary } \\
\text { (g/100 g b.w.) }\end{array}$} & \multicolumn{2}{|c|}{ Uterus (g/100 g b.w.) } & \multirow{2}{*}{$\begin{array}{c}\text { Ovary } \\
\text { (g/100 g b.w.) }\end{array}$} & \multirow{2}{*}{$\begin{array}{c}\text { Vagina } \\
\text { (g/100 g b.w.) }\end{array}$} \\
\hline & & & wet & blotted & & \\
\hline Vehicle & $181.3 \pm 7.1$ & $0.038 \pm 0.005$ & $1.26 \pm 0.30$ & $1.14 \pm 0.28$ & $0.34 \pm 0.03$ & $0.66 \pm 0.10$ \\
\hline NP 10 & $190.6 \pm 9.5$ & $0.033 \pm 0.018$ & $1.58 \pm 0.51$ & $1.25 \pm 0.38$ & $0.36 \pm 0.03$ & $0.68 \pm 0.10$ \\
\hline NP 100 & $184.6 \pm 10.5$ & $0.044 \pm 0.006$ & $2.01 \pm 0.84^{*}$ & $1.69 \pm 0.45^{*}$ & $0.34 \pm 0.04$ & $0.70 \pm 0.07$ \\
\hline ATR 100 & $190.6 \pm 9.5$ & $0.038 \pm 0.008$ & $1.56 \pm 0.46$ & $1.37 \pm 0.23$ & $0.32 \pm 0.04$ & $0.66 \pm 0.09$ \\
\hline
\end{tabular}

The data is presented as means $\pm \mathrm{SD}(\mathrm{n}=10)$. ${ }^{*}$ Significantly different from the controls by Dunnett's test $(\mathrm{P}<0.05)$. 
exposure did not affect reproductive organ weights compared with the controls (Table 2).

\section{Mammary gland development}

To evaluate the effects of NP and ATR following gestational exposure on MG development in the female offspring, whole mount analyses of fourth and fifth MGs were compared on PND 4, 22, 33 and 41 (Fig. 2 and Table 3), and 66 (not shown). The majority of MG development takes place postnatally at the onset of puberty. Although very little growth of the MG gland is common at PND 4, $100 \mathrm{mg} / \mathrm{kg}$ NP induced strong branching of the primary duct to the secondary duct and good migration to lymph nodes, which are located in each of the fat pads [25] and are often used as a landmark when examining histological sections or whole mounts. TEBs are important sites of epithelial cell proliferation during puberty and are responsible for ductal elongation and branching. TEBs are apparent in rats after 2 weeks of age and reach their maximum number by $21-28$ days of age [18]. On PND 22, there were no apparent differences in growth and development between the high dose NP glands and the controls. However, the mammary tissue of the low dose NPand ATR-exposed females contained fewer primary branches from the collecting duct and delayed migration of the epithelium to the lymph node. On PND 33, the high dose NP-exposed females showed more $\mathrm{ABs}$ and good differentiation of TEBs into ABs compared with the corn oiltreated controls, and these patterns of development and migration were detectable in the whole mounts. The ATR-induced delay and stunting of MG development was persistent throughout the experiment period. The sparse nature of branching and slowed epithelial migration through the fat pad were quite apparent.

\section{Immunohistochemistry}

MG consists of both epithelial and stromal tissues. MG morphogenesis and function is based on the ability of specific mammary cell types to respond to ovarian steroid hormones, estrogen and progesterone, and the pituitary hormone prolactin. With the onset of puberty at 4- to 5-week of age, the estrogen produced by the ovaries stimulated ductal elongation by increasing the level of epithelial and stromal cell proliferation in the end buds and surrounding stroma, respectively. The actions of the ovarian steroid hormones on ephithelial and stromal cells in the MG depend on the presence of their nuclear ER and progesterone receptors (PR) [30]. Immunohistochemical comparisons between the mammary or uterus sections were carried out using the appropriate antibodies for ER, PR, and PRLR expressed in a PND $41 \mathrm{MG}$ and uterus (Figs. 3 and 4). Fig 3 shows a low level of ER in the stroma and epithelium of control glands and a higher level in the tissue of pups exposed to NP. ATR also increased the level of ER in the stroma surrounding the TEBs. PR was observed at high levels in the epithelium of $10 \mathrm{mg} / \mathrm{kg}$ NP glands and was even more prominent in the ATR-exposed ductal epithelium. However, PR staining was markedly lower in the epithelium of the $100 \mathrm{mg} / \mathrm{kg}$ NP glands compared with the control glands (Fig. 3). Similar immunohistochemical staining patterns for the glands were observed in the ER and PR expressed in the uterus body epithelium (Fig. 4). The color of the staining for PR detection with the appropriate antibody was lighter than that of the control uterine epithelium. The level of PRLR staining was higher than the control levels in only the NP-exposed mammary glands containing lobule areas. These qualitative evaluations show that NP and ATR have opposite effects on MG and uterus development after gestational exposure.

\section{Hormone measurements}

In this study, the serum hormone levels were measured in PND 41 female offspring exposed to NP in the late pregnant period on PND 41. The serum hormone concentrations were evaluated individually in all female rats regardless of the stage of the estrous cycle. There were significant decreases in the pituitary LH and TSH levels of the pups exposed to $100 \mathrm{mg} / \mathrm{kg}$ NP during the gestation period compared with the controls. However, there were no corresponding increases in the concentrations of these hormones in the serum (Fig. 5).

\section{Discussion}

The results of this study demonstrate that brief exposure to $100 \mathrm{mg} / \mathrm{kg} \mathrm{NP}$ in late pregnancy can cause precocious MG development in female offspring. NP $(100 \mathrm{mg} / \mathrm{kg})$ produced strong branching of the primary duct into multiple 


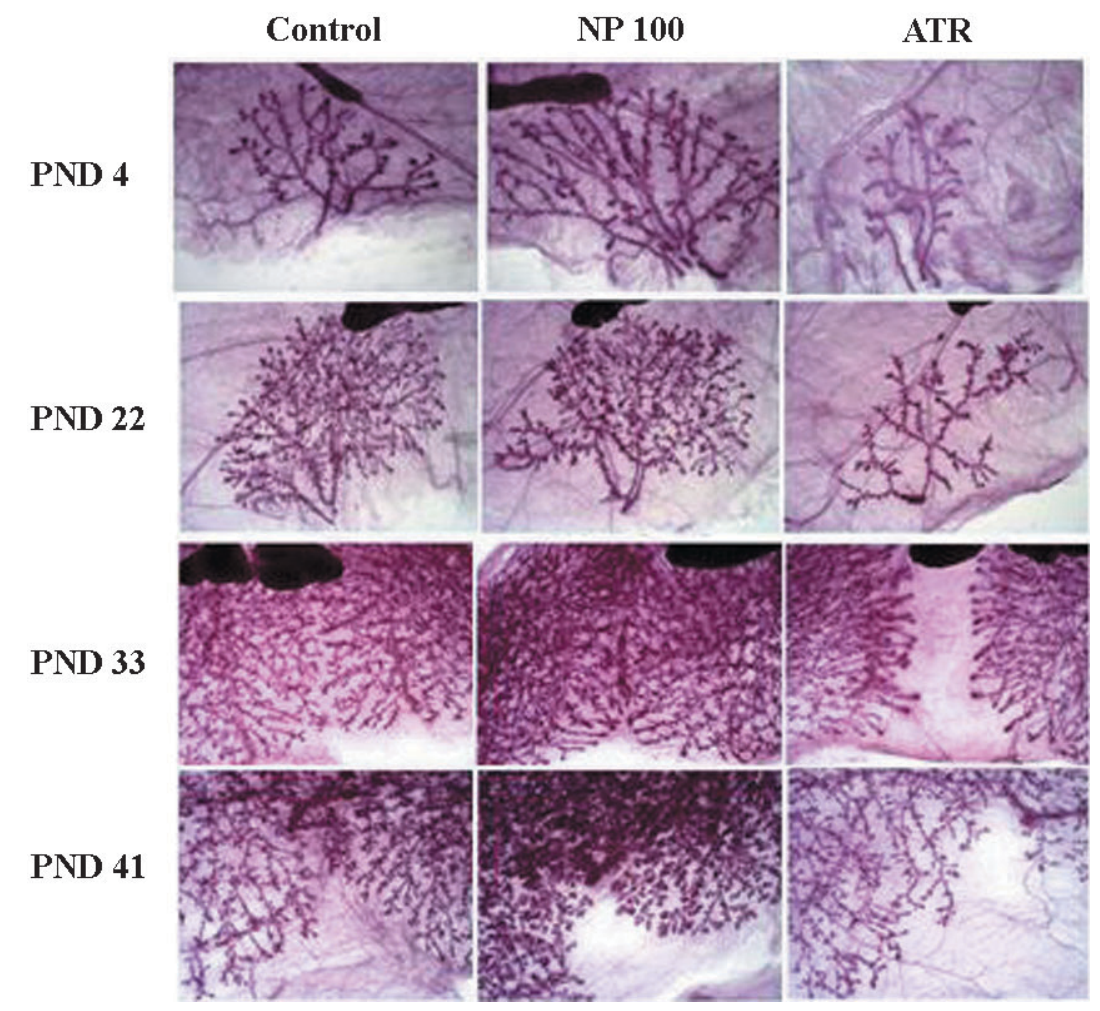

Fig. 2. Carmine-stained wholemount preparations of mammary gland from postnatal days (PND) 4, 22, 33 and 41 . The fourth and fifth glands of female offspring exposed to nonylphenol (NP) or atrazine (ATR) were removed, fixed, and stained with carmine. $\times 20$.

Table 3. The effect of nonylphenol (NP) and atrazine (Atr) on mammary gland development and differentiation in female offspring rats

\begin{tabular}{|c|c|c|c|c|}
\hline & & \multicolumn{3}{|c|}{ Treatment (mg/kg/day) } \\
\hline & & Control & NP 100 & Atr 100 \\
\hline \multirow[t]{3}{*}{ PND 4} & Primary branches & $2.8 \pm 0.5$ & $2.5 \pm 0.6$ & $2.2 \pm 1.0$ \\
\hline & Score $^{\mathrm{a}}$ & $2.8 \pm 0.3$ & $2.5 \pm 0.6$ & $1.5 \pm 0.5$ \\
\hline & Migration $^{b}$ & - & ++ & - \\
\hline \multirow[t]{3}{*}{ PND 22} & Score of structure & $3.0 \pm 0.7$ & $3.3 \pm 0.7$ & $2.1 \pm 0.9$ \\
\hline & Score $^{c}$ & $3.3 \pm 0.4$ & $3.4 \pm 0.5$ & $3.5 \pm 0.6$ \\
\hline & Migration & +++ & +++ & + \\
\hline \multirow[t]{2}{*}{ PND 33} & Score $^{\mathrm{d}}$ & $2.9 \pm 0.5$ & $2.7 \pm 0.6$ & $2.2 \pm 0.7$ \\
\hline & Distance $(\mathrm{mm})^{\mathrm{e}}$ & $0.04 \pm 0.10$ & $0.49 \pm 1.10$ & $1.23 \pm 1.23^{*}$ \\
\hline PND 41 & Score $^{\mathrm{f}}$ & $3.0 \pm 0.3$ & $3.3 \pm 0.4$ & $2.5 \pm 0.5$ \\
\hline
\end{tabular}

a Scoring of the structure of the tree and the number of terminal buds.

${ }^{\mathrm{b}}$ Migration of the mammary gland from the nipple to the lymph node.

$c, d$ Scoring of the number of terminal end buds and alveolar buds.

e The shortest distance in the interface between the inguinal $4^{\text {th }}$ and $5^{\text {th }}$ glands.

${ }^{\mathrm{f}} \mathrm{S}$ coring of the degree of differentiation of the terminal end buds into the alveolar buds.

$\mathrm{N}=5$ animals per group except PND $41(\mathrm{n}=10)$.

Data are means $\pm S D$, and values in parentheses are the numbers of animals analyzed.

*Significantly different from the corn oil-treated controls $(\mathrm{P}<0.05)$. 
$\begin{array}{lll}\text { Control NP 100 ATR } & \text { ATR }\end{array}$

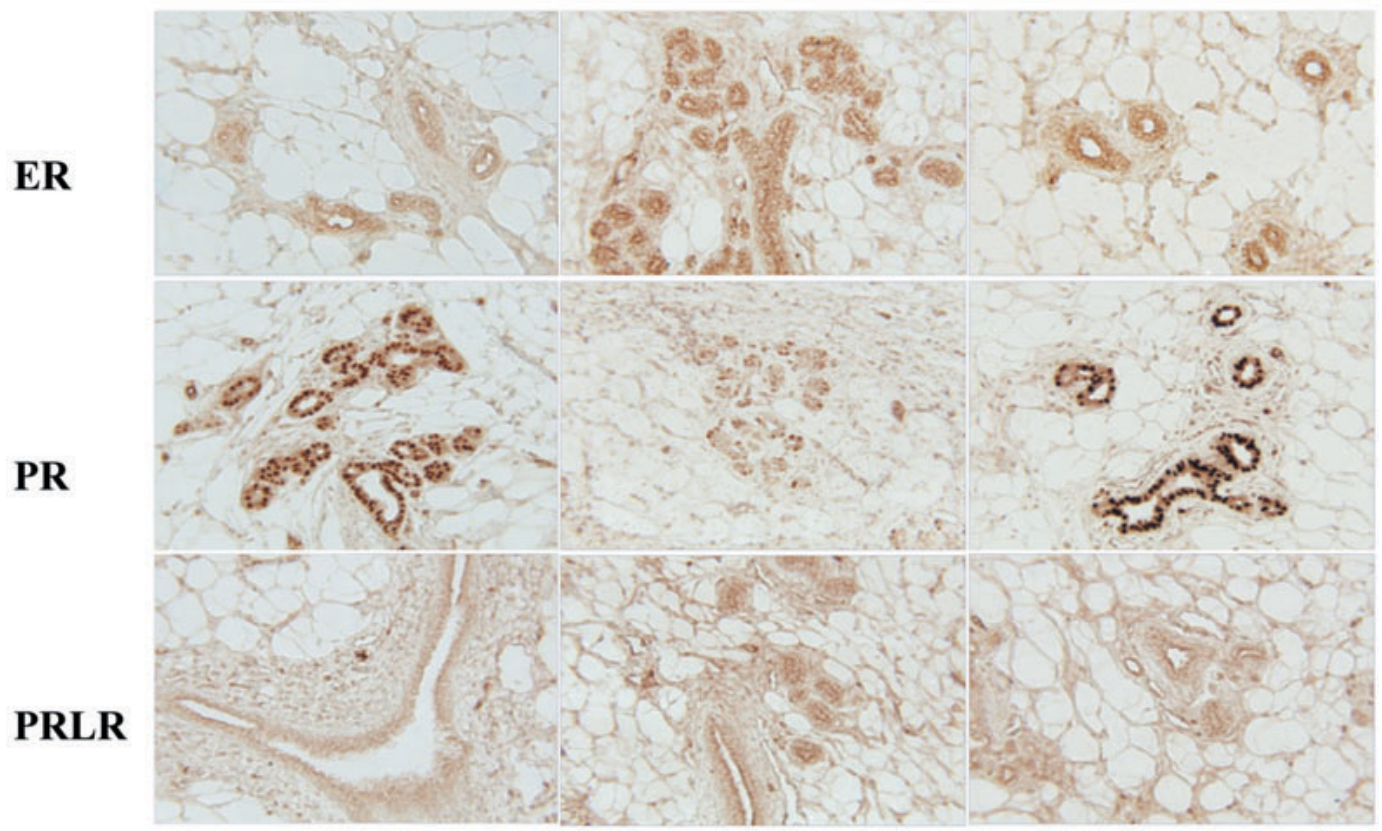

Fig. 3. Immunohistochemistry of representative sections from female offspring mammary glands (PND 41) in utero-exposed to nonylphenol (NP) or atrazine (ATR) for estrogen (ER), progesterone (RR) and prolactin receptor (PRLR). Diaminobenzidine-stained mammary epithelial and stromal cells were found in terminal end buds, ducts, and lobules in both the NP- and ATR-exposed and non-exposed control glands. $\times 25$.

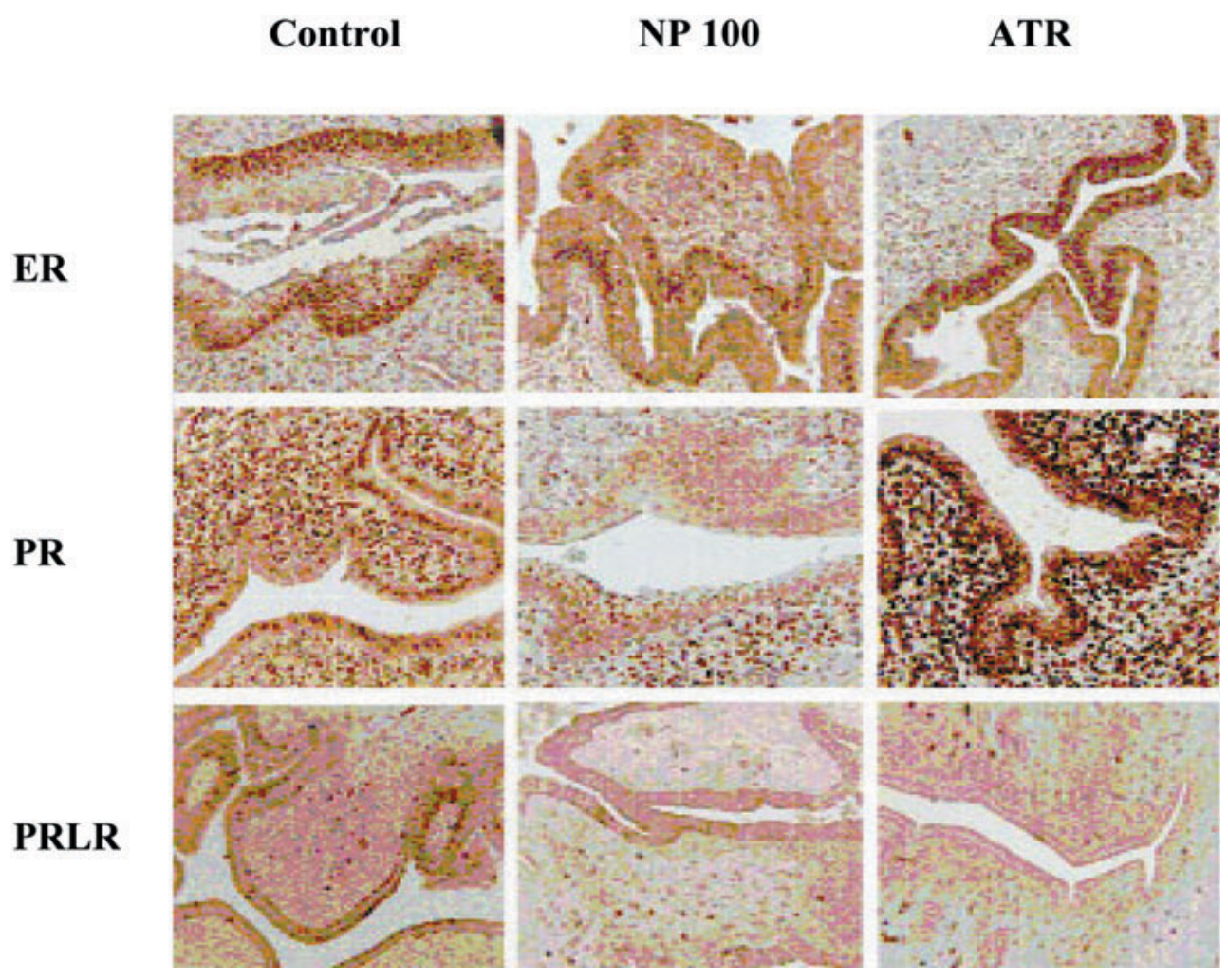

Fig. 4. Immunohistochemistry of representative sections of uterus obtained from female offspring (PND 41) exposed in utero to nonylphenol (NP) or atrazine (ATR) for estrogen (ER), progesterone (RR) and prolactin receptor (PRLR). Diaminobenzidine-stained epithelial and stromal cells were found in the uterus body in both the NP- and ATR-exposed and non-exposed control uterus. $\times 25$. 

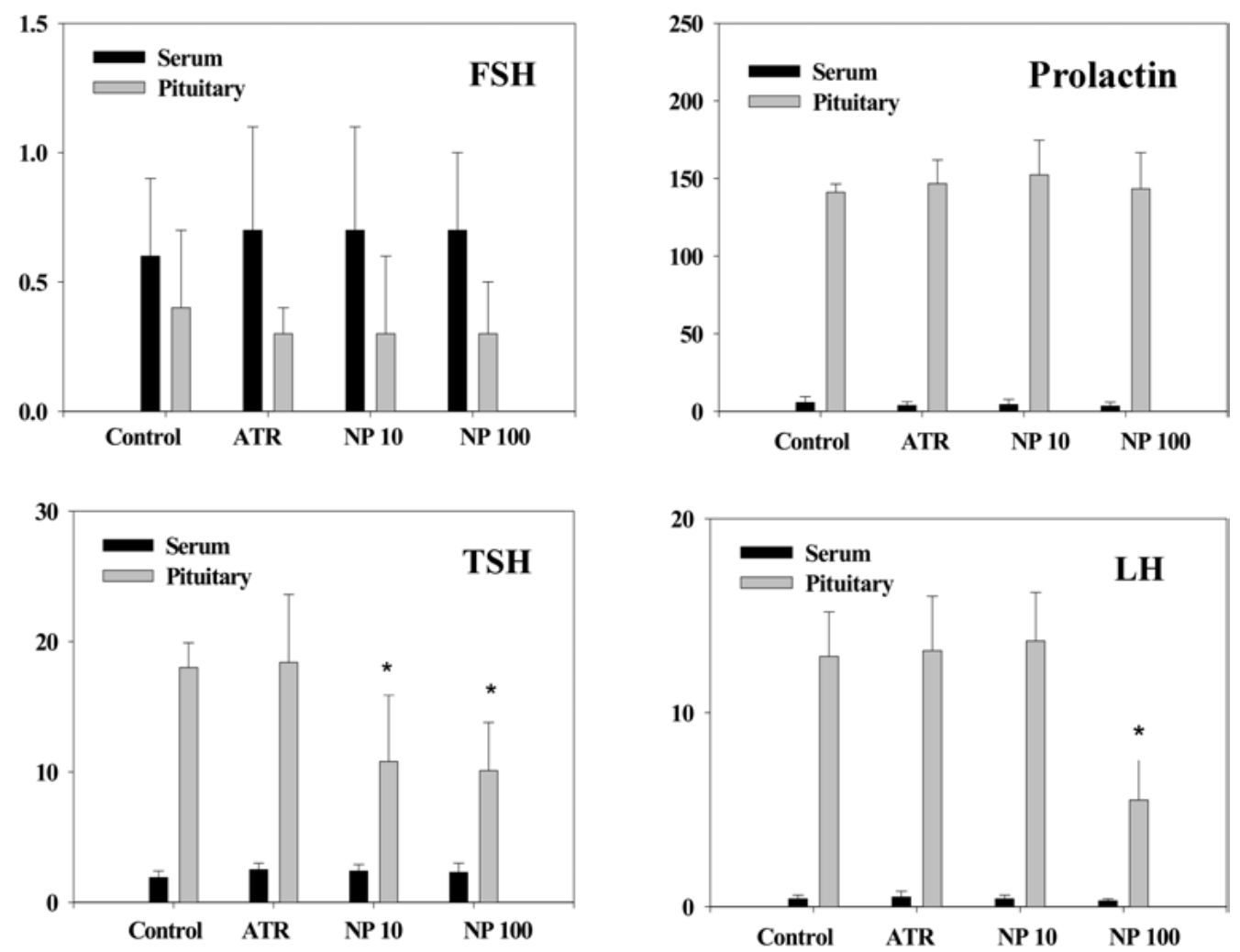

Fig. 5. Hormone concentrations of Long Evans female offspring rats in utero-exposed to nonylphenol (NP) or atrazine (ATR). Each panel shows the serum (black bars) and pituitary (shaded bars) concentrations of FSH, prolactin, TSH and LH in the female offspring at necropsy (PND 41). The data is presented as means $\pm S D(n=10)$. * Significantly different from the control by Dunnet's test $(\mathrm{P}<0.05)$

secondary ducts from PND 4, promoted proliferation of the mammary epithelium on PND 22 and 33 , and caused precocious differentiation of immature TEBs into mature structures (i.e., lobules) on PND 41 (Fig. 2). It should be noted that susceptibility to chemicals in rats is linked to differentiation of MG cells [27, 32-34], and the terminal ductal structures of MG are sensitive to hormonal influence $[35,36]$. In addition, an early estrogen treatment protects against carcinogeninduced MGs [35-38], and less proliferative lobules are less susceptible to the actions of carcinogens than TEBs [32]. This study suggests that NP may play a role in the cell proliferation of the MG, including the possibility that estrogen-like chemicals act as cancer promoters if given after a genotoxic carcinogen [39].

The estrogenic effect of NP in the MG does not appear to be the effect of residual NP remaining in body of the offspring. The aerobic first order biodegradation half-life of NP is 20 days in the OECD $310 \mathrm{~F}$ method for evaluating the biodegradability of a test substance by microorganism [40], and primary biodegradation of nonylphenol ethoxylate to NP is relatively rapid [2]. Current research [41] confirms that single doses of NP ( 5 or $200 \mathrm{mg} / \mathrm{kg}$ ) are rapidly excreted and that NP does not accumulate in the tissues of rats. It is not presumed that residual NP affects the reproductive organs and MG during the total period required for this experiment. Therefore, these results, demonstrating that the increased numbers of TEBs and early differentiation into the ABs observed after in utero NP exposure, suggest that the undeveloped rat mammary tissue is susceptible to NP. However, further study is required to determine the mechanism of action for NP in mammary development following prenatal exposure.

Steroid biological activity is mediated by binding 
to specific intracellular proteins known as steroid receptors [42]. NP can compete with estradiol for binding to the ER and demonstrate estrogen-like activity both in vivo and in vitro with potencies of approximately $10^{-4}$ to $10^{-7}$ relative to estradiol [4448]. There are some reports showing PR expression by NP in MGs. Tran et al. [49] reported that NP functions as a dose-dependent antagonist of human PR (hPR) in yeast, and the inhibition of hPR activity by NP occurs at the level of the receptor, as indicated by competition binding assays in yeast. They also suggested that the estrogenic activity of some synthetic estrogens might be enhanced by functioning as inhibitors of hPR. Several other studies have also demonstrated that $\mathrm{PR}$ reduces ER-mediated transactivation $[50,51]$. On the other hand, there are some reports showing that NP can induce PR expression and cellular proliferation in MCF-7 cells [44], and PR expression can serve as a marker for both E2 and progesterone action during various physiological states in MGs [52]. Based on the above results, this study examined whether or not expression of ER, PR, or PRLR in the mammary epithelium or stroma is related to development of the MGs of female pups exposed to NP during pregnancy. As expected, immunohistochemical staining showed that in utero NP exposure increased expression of ER or PRLR in the epithelial and stromal cells of female MGs in a dosedependent manner. However, expression of PR was reduced in epithelial and stromal cells by a high dose of NP (Fig. 3). Because different types of cell express PR, more study is required to identify the inhibition of PR expression by NP in the MG.

The ATR-exposed MGs showed obvious poor epithelial elongation and differentiation into lobules throughout the experimental period (Fig. 2). Although it is not known whether ATR is directly responsible for the altered growth of the pup gland early in life, Rayner et al. [19] suggested that prenatal exposure to ATR can decrease aromatase and epidermal growth factor receptor EGFR expression in the MG of female offspring rats. It has also been reported that aromatase activity by estrogen in breast and stromal EGFR is required to induce ductal growth and branching morphogenesis [53-57]. The increase in the ER or PR expression levels in the gland might simply be a reflection of the percentage of terminal end buds observed in the less differentiated ATR-exposed glands. It is possible to increase the incidence of mammary tumors when TEBs distributed in MGs exposed to ATR in late pregnancy are exposed to a carcinogen postnatally. Moreover, such a decrease in differentiation appears to correlate with impaired MG development.

Although estrogen and progesterone have profound effects on MG development, thyroid hormones have been found to play a direct role in growth and differentiation of the MG in rodent models [58-61]. This effect is attributed, in part, to the induction of increased sensitivity of the tissues to estradiol and prolactin by modulating the number and affinity characteristics of their respective receptors [59]. Hypothyroidism in mice is associated with delayed lobuloalveolar development and a greater degree of postlactational involution of the MG. Although the serum TSH level in female offspring exposed to NP was unchanged, the decrease in the pituitary TSH level might be due to the increase in serum thyroid hormone. This study suggests that the thyroid hormone may partially promote growth and differentiation of the female MG in utero-exposed to NP.

The uterine weights on PND 41 were significantly higher in the female offspring exposed to a high dose of NP compared with the controls (Table 2). This result is consistent with reports showing that NP at 650 ppm (calculated dose range, $30-100 \mathrm{mg} / \mathrm{kg}$ ) increased the weight of the uterus/vagina of F1 females in a rat multigeneration study $[12,31]$.

In summary, the females exposed to NP in late pregnancy showed similar uterotrophic responses to estradiol in the reproductive organs and promotions of normal differentiation in the MG. On the other hand, the ATR-exposed females showed less differentiation and were more susceptible to lobules in the MG throughout mammary development.

\section{References}

1. Ahel M, McEvoy J, Giger W. Bioaccumulation of the lipophilic metabolites of nonionic surfactants in freshwater organisms. Environ Pollut 1993; 79: 243.

2. Naylor CG. Environmental fate of alkylphenol 
ethoxylates. Soap Cosmet Chem Spec 1992; 68: 27.

3. Li MH, Wang ZR. Effect of nonylphenol on plasma vitellogenin of male adult guppies (Poecilia reticulata). Environ Toxicol 2005; 20: 53-59.

4. Pait AS, Nelson JO. Vitellogenesis in male Fundulus heteroclitus (killifish) induced by selected estrogenic compounds. Aquat Toxicol 2003; 64: 331342 .

5. Jobling S, Sumpter JP. Detergent components in sewage effulents are weakly oesftrogenic to fish: an in vitro study using rainbow trout (Oncorhynchus mykiss) hepatocytes. Aquat Toxicol 1993; 27: 361-372.

6. White R, Jobling S, Hoare SA, Sumpter JP, Parker MG. Environmentally persistent alkylphenolic compounds are estrogenic. Endocrinology 1994; 135: 175-182.

7. Hunag YN, Cheng WB, Xu PY, Yu WS, Li QY, Wang WD, Wang ZS, Pang DQ, Liu YQ. Exploring the sensitive indicators of uterotrophic assay in immature SD rats exposed to para-nonylphenol. Sichuan Da Xue Xue Bao Yi Xue Ban 2004; 35: 87-90 (in Korean).

8. Owens W, Ashby J, Odum J, Onyon L. The OECD program to validate the rat uterotrophic bioassay. Phase 2: dietary phytoestrogen analyses. Environ Health Perspect 2003; 111: 1559-1567.

9. Odum J, Lefevre PA, Tittensor S, Paton D, Routledge EJ, Beresford NA, Sumpter JP, Ashby J. The rodent uterotrophic assay: critical protocol features, studies with nonyl phenols, and comparison with a yeast estrogenicity assay. Regul Toxicol Pharmacol 1997; 25: 176-188.

10. Chapin RE, Davis BJ, Delaney JC, Kaiser LB, Wang Y, Lanning LL, Wolfe HW. Multigenerational study of 4-nonylphenol in rats. Toxicologist 1998; 42: 100.

11. Laws SC, Carey SA, Ferrell JM, Bodman GJ, Cooper RL. Estrogenic activity of octylphenol, nonylphenol, bisphenol A and methoxychlor in rats. Toxicol Sci 2000; 54: 154-157.

12. Nagao T, Wada K, Marumo H, Yoshimura S, Ono H. Reproductive effects of nonylphenol in rats after gavage administration: a two-generation study. Reprod Toxicol 2001; 15: 293-315.

13. Colerangle JB, Roy D. Exposure of environmental estrogenic compound nonylphenol to Noble rats alters cell-cycle kinetics in the mammary gland. Endocrine 1996; 4: 115-122.

14. Odum J, Pyrah ITG, Foster JR, Van Miller JP, Joiner RL, Ashby J. Comparative activities of $\mathrm{p}$ Nonylphenol and diethylstilbestrol in Noble rat mammary gland and uterotrophic assays. Regul Toxicol Pharmacol 1999; 29: 184-195.

15. Stevens TT, Breckenridge CB, Wet zel LT, Gillis JH, Luempert LG, Eldridge JC. Hypothesis for mammary tumorigenesis in Sprague-Dawley rats exposed to certain triazine herbicides. J Toxicol Environ Health 1994; 43: 139-153.
16. Wetzel LT, Luempert LG 3rd, Breckenridge CB, Tisdel MO, Stevens JT, Thakur AK, Extrom PJ, Eldridge JC. Chronic effects of atrazine on estrus and mammary tumor formation in female SpragueDawley and Fischer 344 rats. J Toxicol Environ Health 1994; 43: 169-182.

17. Laws SC, Ferrell JM, Stoker TE, Schmid J, Cooper RL. The effects of atrazine on female Wistar rats: an evaluation of the protocol for assessing pubertal development and thyroid function. Toxicol Sci 2000; 58: 366-376.

18. Cooper RL, Stoker TE, Goldman JM, Parrish MB, Tyrey L. Effect of atrazine on ovarian function in the rat. Reprod Toxicol 1996; 10: 257-264.

19. Rayner JL, Wood C, Fenton SE. Exposure parameters necessary for delayed puberty and mammary gland development in Long-Evans rats exposed in utero to atrazine. Toxicol Appl Pharmacol 2004; 195: 23-34.

20. Rayner JL, Enoch RR, Fenton SE. Adverse effects of prenatal exposure to atrazine during a critical period of mammary gland growth. Toxicol Sci 2005; 87: 255-266.

21. Eldridge JC, Wetzel LT, Stevens JT, Simpkins JW. The mammary tumor response in triazine-treated female rats: a threshold-mediated interaction with strain and species-specific reproductive senescence. Steroids 1999; 64: 672-678.

22. Eldridge JC, Wetzel LT, Tyrey L. Estrous cycle patterns of Sprague-Dawley rats during acute and chronic atrazine administration. Reprod Toxicol 1999; 13: 491-499.

23. Sharpe RM, Skakkebaek NE. Are oestrogens involved in falling sperm counts and disorders of the male reproductive tract? Lancet 1993; 341: 1392 1395.

24. Gray LE, Kelce WR. Latent effects of pesticides and toxic substances on sexual differentiation of rodents. Toxicol Ind Health 1996; 12: 515-531.

25. Topper YJ, Freeman CS. Multiple hormone interactions in the developmental biology of the mammary gland. Physiol Rev 1980; 60: 1049-1106.

26. Brown NM, Lamartiniere CA. Xenoestrogens alter mammary gland differentiation and cell proliferation in the rat. Environ Health Perspect 1995; 103: 708-713.

27. Russo J, Russo IH. DNA labeling index and structure of the rat mammary gland as determinants of its susceptibility to carcinogenesis. J Natl Cancer Inst 1978; 61: 1451-1459.

28. Dulbecco R, Henahan M, Armstrong B. Cell types and morphogenesis in the mammary gland. Proc Natl Acad Sci USA 1982; 79: 7346-7350.

29. Cooper RL, Stocker TE, Tyler L, Goldman JM, McElroy WE. Atrazine disrupts the hypothalamic control of pituiatary-ovarian function. Toxicol Sci 2000; 53: 297-307. 
30. Haslam SZ. Role of sex steroid hormones in normal mammary gland function. In: Neville MC, Daniel CW (eds.), The Mammary Gland, Development, Regulation and Function. New York: Plenum Press, 1987; 499-533.

31. Chapin RE, Delaney J, Wang Y, Lanning L, Davis B, Collins B, Mintz N, Wolfe G. The effects of 4nonylphenol in rats: a multigeneration reproduction study. Toxicol Sci 1999; 52: 80-91.

32. Lamartiniere CA, Moore J, Holland M, Barnes S. Neonatal genistein chemoprevents mammary cancer. Proc Soc Exp Biol Med 1995; 208: 120-123.

33. Murrill WB, Brown NM, Zhang JX, Manzolillo PA, Barnes S, Lamartiniere CA. Prepubertal genistein exposure suppresses mammary cancer and enhances gland differentiation in rats. Carcinogenesis 1996; 17: 1451-1457.

34. Russo IH, Russo J. Mammary gland neoplasia in long-term rodent studies. Environ Health Perspect 1996; 104: 938-967.

35. Grubbs CJ, Farnell DR, Hill DL, McDonough KC. Chemoprevention of $\mathrm{N}$-nitroso- $\mathrm{N}$-methylureainduced mammary cancers by pretreatment with 17 beta-estradiol and progesterone. J Natl Cancer Inst 1985; 74: 927-931.

36. Welsch CW. Host factors affecting the growth of carcinogen-induced rat mammary carcinomas: a review and tribute to Charles Brenton Huggins. Cancer Res 1985; 45: 3415-3443.

37. Shellabarger CJ, Soo VA. Effects of neonatally administered sex steroids on 7,12-dimethylbenz(a)anthracene-induced mammary neoplasia in rats. Cancer Res 1973; 33: 1567-1569.

38. Nagasawa $H$, Yanai $R$, Shodono $M$, Nakamura T, Tanabe Y. Effect of neonatally administered estrogen or prolactin on normal and neoplastic mammary growth and serum estradiol-17 beta level in rats. Cancer Res 1974; 34: 2643-2646.

39. Scribner JD, Mottet NK. DDT acceleration of mammary gland tumors induced in the male Sprague-Dawley rat by 2-acetamidophenanthrene. Carcinogenesis 1981; 2: 1235-1239.

40. Staples CA, Williams JB, Blessing RL, Varineau PT. Measuring the biodegradability of nonylphenol ether carboxylates, octylphenol ether carboxylates, and nonylphenol. Chemosphere 1999; 38: 2029-2039.

41. Fannell TR, MacMeela JP. Disposition and metabolism of p-nonyl phenol in male and female rats. Toxicologist 1997; 36: 142.

42. Ing $\mathbf{N H}, \mathbf{O}^{\prime}$ Malley $\mathbf{B W}$. The steroid hormone receptor superfamily-molecular mechanisms of action. In: Molecular Endocrinology: Basic Concepts and Clinical Correlations. New York: Raven Press, 1995; 195-215.

43. Fenton SE, Hamm JT, Birnbaum LS, Youngblood GL. Persistent abnormalities in the rat mammary gland following gestational and lactational exposure to 2,3,7,8-tetrachlorodibenzo-p-dioxin (TCDD). Toxicol Sci 2002; 67: 63-74.

44. Soto AM, Honorato J, Wray JW, Sonnenschein C. Nonylphenol: An estrogenic xenobiotic released from "modified" polystyrene. Environ Health Perspect 1991; 92: 167-173.

45. Flouriot G, Pakdel F, Ducouret B, Valotaire Y. Influence of xenobiotics on rainbow trout liver estrogen receptor and vitellogenin gene expression. J Mol Endocrinol 1995; 15: 143-151.

46. Soto AM, Sonnenschein C, Chung KL, Fernandez MF, Olea N, Serrano FO. The E-SCREEN assay as a tool to identify estrogens: An update on estrogenic environmental pollutants. Environ Health Perspect 1995; 103: 113-122.

47. Lech JJ, Lewis SK, Ren L. In vitro estrogenic activity of 4-nonylphenol in rainbow trout. Fundam Appl Toxicol 1996; 30: 229-232.

48. Ren LF, Lewis SK, Lech JJ. Effects of estrogen and nonylphenol on the post-transcriptional regulation of vitellogenin gene expression. Chem Biol Interact 1996; 100: 67-76.

49. Tran DQ, Klotz DM, Ladlie BL, Ide CF, McLachlan JA, Arnold SF. Inhibition of progesterone receptor activity in yeast by synthetic chemicals. Biochem Biophys Res Commun 1996; 229: 518-523.

50. Wen DX, Xu YF, Mais DE, Goldman ME, McDonnell DP. The A and B isoforms of the human progesterone receptor operate through distinct signaling pathways within target cells. Mol Cell Biol 1994; 14: 8356-8364.

51. Kraus WL, Weis KE, Katzenellenbogen BS. Inhibitory cross-talk between steroid hormone receptors: differential targeting of estrogen receptor in the repression of its transcriptional activity by agonist- and antagonist-occupied progestin receptors. Mol Cell Biol 1995; 15: 1847-1857.

52. Haslam SZ, Shyamala G. Relative distribution of estrogen and progesterone receptors among the epithelial, adipose, and connective tissue components of the normal mammary gland. Endocrinology 1981; 108: 825-830.

53. Sebastian J, Richards RG, Walker MP, Wiesen JF, Werb Z, Derynck R, Hom YK, Cunha GR, DiAugustine RP. Activation and function of the epidermal growth factor receptor and erbB-2 during mammary gland morphogenesis. Cell Growth Differ 1998; 9: 777-785.

54. Li X, Warri A, Makela S, Ahonen T, Streng T, Santti R, Poutanen M. Mammary gland development in transgenic male mice expressing human P450 aromatase. Endocrinology 2002; 143: 4074-4083.

55. Sasano $\mathbf{H}$, Harada N. Intratumoral aromatase in human breast, endometrial, and ovarian malignancies. Endocr Rev 1998; 19: 593-607.

56. Oka T, Yoshimura M, Lavandero S, Wada K, Ohba 
Y. Control of growth and differentiation of the mammary gland by growth factors. J Dairy Sci 1991; 74: 2788-2800.

57. Wiesen JF, Young P, Werb Z, Cunha GR. Signaling through the stromal epidermal growth factor receptor is necessary for mammary ductal development. Development 1999; 126: 335-344.

58. Vonderhaar BK, Greco AE. Effect of thyroid status on development of spontaneous mammary tumors in primiparous C3H mice. Cancer Res 1982; 42: 45534561.

59. Vonderhaar BK. Effect of thyroid hormones on mammary tumor induction and growth. In: Leung
BS (ed.), Hormonal Regulation of Experimental Mammary Tumors. New York: Pergamon Press, 1982; 138-154.

60. Vonderhaar BK. Hormones and growth factors in mammary gland development. In: Venezial CM (ed.), Control of Cell Growth and Proliferation. New York: Van Nostrand and Reinhold, 1984; 11-33.

61. Vonderhaar BK. Prolactin: transport, function, and receptors in mammary gland development and differentiation. In: Neville MC, Daniel CW (eds.), The Mammary Gland: Development, Regulation and Function. New York: Plenum Press, 1987; 383438. 